\title{
Research on the Multimedia Teaching Model Based on Campus Network
}

\author{
Chen Xueyan", a, Mei Chunli ${ }^{1 *}, \mathrm{~b}$ \\ 1 Beihua University, Jilin, 132031, China \\ aemail:455931074@qq.com, bemail:meixiaoqing2007@126.com
}

(Mei Chunli*is responding author)

\begin{abstract}
Keywords:Campus network;Multimedia teaching model;Traditional teaching model;Virtual reality technology

Abstract. As the core equipment for a university, campus network plays an important role in various aspects of the university. The multimedia network technology based on it has greatly changed the traditional way of education. The introduction of advanced technology has significantly improved teaching efficiency, and also greatly improved teaching quality. Starting from the definition of campus network and the formulation of multimedia teaching model, this paper emphasizes their combination to construct a multimedia teaching model based on campus network, and puts forward the advantages and future of the model. Based on practice, the writer discusses some problems existing in multimedia teaching and makes prospects for its development in the future. The writer's contribution is to propose the necessity of multimedia network teaching and propose the solutions to its shortcomings through a demonstration, hoping to make a contribution to the research of multimedia network teaching.
\end{abstract}

\section{Introduction}

The campus network is the core of information resources in colleges and universities, as an extension of the network, the use of modern network information technology, schools will be a variety of information resources in one set[1]. And the campus network can continue to gather new information, for the various functional departments of the school provides a wealth of network literature information, in the school education and teaching plays a pivotal role. The construction of the campus network for the realization of the educational resource sharing various colleges and universities of our country, laid a solid foundation to promote information exchange and cooperative work.

\section{Multimedia Teaching Mode}

In the past, the old teaching method can not adapt to today's information network, as the center of the education system[2]. To the high-speed information age, to keep up with the pace of social progress, we must explore an effective teaching mode to improve teaching efficiency, improve the quality of teaching to the teaching. Model, it is a kind of structure form can reflect the relationship between the elements of teaching, including teaching mode and learning mode and relevant teaching strategies. It can affect the transformation of teaching ideas, concepts, theory, education system can even be changed. So, every change in effective teaching mode, all education will make a big step forward. With the rapid development of multimedia technology, multimedia technology has been widely used in many aspects of society. This includes people with The education progress closely related. In the continuous exploration of people under the new teaching mode of multimedia teaching mode in universities. It is the teacher according to the teaching demand, multimedia auxiliary tool, and the teaching content in the image, sound, text and other forms of effective, flexible reflected, so that students can be more efficient to accept a new mode of knowledge. It makes students learning ability has been greatly improved, but also on the quality of teaching has been greatly improved. 


\section{Multimedia teaching mode based on campus network}

The new multimedia teaching mode is the combination of multimedia teaching and campus network platform, and applied in the classroom teaching and extracurricular learning, in order to realize the innovation and optimization of the multimedia teaching process.

\section{The Advantages of Multimedia Teaching Mode Based on Campus Network}

The teaching mode is a kind of stable structure form of teaching activity, which is based on the current teaching environment. It not only embodies the mutual contact between the teaching theory and the teaching practice of teaching and learning as the intermediary and bridge, and in the teaching design, teaching activities, teaching effect evaluation process plays a certain reference function[3]. In Colleges and universities, modern teaching methods can be divided into the following three categories: the traditional teaching mode, multimedia teaching mode, based on the campus network (open) multimedia teaching mode.

The Traditional Teaching Mode

The traditional teaching mode(teacher-blackboad-student) mostly take the teacher writing on the blackboard teaching methods, the effect of classroom teaching is to form a single, boring content. The teaching mode from the objective view, attention points, despise the ability to ignore the overall quality of training; in terms of operation that means backward, simple process, lack of creativity and practice; see, pays attention to the present, from quick time, not for the future development of information transmission; from the point of view, a small amount of information, students lack of information processing system from the point of view of freedom; teacher-student relationship, teacher centered, students are passive.

The Simple Multimedia Teaching Mode

Based on the traditional teaching mode, the multimedia device will teaching information with images, sound, graphics, text and other forms of visual presentation, vivid role in classroom teaching activities. The teaching mode of teachers to take most of the use of mobile storage devices for courseware copy and to a certain extent. To optimize the teaching process, to stimulate students thinking, cultivate students' ability to analyze and solve problems. The teaching mode is more common in Colleges and universities, while overcoming the drawbacks of the traditional teaching mode, but due to its single teaching mode, the teaching materials for teachers to use a single, lack of completely unmasked old, so as to make teaching the effect has been to a certain extent.

Multimedia Teaching Mode Based on Campus Network (Open Multimedia Teaching Mode) This mode can exert the advantages of multimedia teaching, data interconnection function and can through the campus network, multimedia teaching into the shared resources, because of this It is mainly characterized by openness, interactivity. Breaking the traditional classroom demonstration teaching into classroom and extracurricular, and improve teaching, learning and exchange of diversified teaching mode. Figure 3 is based on the campus network (open) multimedia teaching mode in summary, can provide better services for the teaching of multimedia teaching mode of campus network based on the teaching, teachers can according to the needs, using the courseware resources service will upload content, teachers can preview in any multimedia teaching platform, make adequate preparation for classroom teaching, students can also through this function to prepare. Teaching, teachers can according to the difficulty of teaching contents and the students' comprehension of knowledge points, the use of multimedia network technology advantage will abstract knowledge in the image, voice and other ways, make the students easy To accept. The teacher can also apply for the whole process of the class can be recorded, after class, and check out the classroom teaching video recording, to know the teaching process students to master teaching content and learning attitude, to make further classroom planning, to promote the teaching process more perfect. In addition, students as teaching objects in an in the classroom teachers learning content at the same time, should also make full use of relevant information in the campus network multimedia teaching resources and the Internet, according to the need to download the study, as an auxiliary means of classroom learning, to supplement their knowledge. 


\section{Thinking of multimedia teaching mode based on campus network}

Based on the teaching mode of multimedia campus network while providing a good convenience for the teaching process, but due to the use of process is not reasonable, there will be some drawbacks[4]. For example: (1) teachers over reliance on the teaching mode, the leading position of its own to the multimedia network, multimedia courseware to replace all and while he was making courseware service, this should be produced. Draw further apart the effect of multimedia and campus network are the rapid development of high technology, although the advanced teaching theory, the right but not the teacher, with the teaching design do not play its due role. Therefore, the teacher should adjust attitude, to the multimedia teaching mode timely and appropriate use of multimedia network, and make their own advantages perfectly reflected. (2) the teacher may be in order to improve the efficiency of classroom teaching, the teaching course Content being too concentrated, in the whole process of teaching, courseware like a movie screen as fleeting, but the students did not have sufficient time to think to hear or see the contents of this down seriously affecting the effectiveness of teaching. Some teachers will do Courseware too complex, the courseware is superfluous, lost the courseware is simple and concise, the teaching focus will shift. (3) the lack of communication between teachers and students, no real sense of the use of multimedia teaching in campus network on the basis of advantages. (4) students as the teaching object, we should make full use of classroom time to use their spare time in the campus network multimedia active teaching platform preview, review the teacher courseware content, truly grasp the content of courseware teachers. (5) campus network and multimedia teaching is a unified organism, any independent operation Can not play its powerful function of information teaching

\section{Conclusions}

In summary, teacher as a new generation Chinese talent guide, he(she) should have a correct understanding of the attachment relationship between the multimedia teaching mode and the campus network, the campus network multimedia teaching platform will gradually become the classroom and extracurricular teaching mode[5]. At the same time also should take the initiative to learn excellent courseware resources on the Internet, filling oneself short, the increase in the amount of information in the process of teaching, as far as possible the important information in a straightforward way reflected in the courseware, for complex or difficult for students to understand the content through multimedia or other means of expression, as a multimedia teaching platform of management personnel, should also strive to integrate teaching resources, build the digital multimedia course center data sharing using campus network, improve the multimedia teaching mode, to adapt to the development of modern educational technology, to meet the need of modern teaching.

\section{Acknowledgements}

This work was financially supported by the Jilin Provincial Department of Education Commission (2015153).

\section{References}

[1] Zhang Jinbao, Huang Ronghuai, Zhang Lian gang. Wisdom education cloud service: open education new mode of education information service [J].2012 (3): 31-33.

[2] Liu Guoqing. The application of modern educational technology in the teaching mode of "independence, interaction and innovation" [J]. China audio visual education, 2004 (2): 34-38.

[3] Guo Ping. Some thoughts on the change of ideas in the development of educational technology [J]. audio visual education research, 2003 (2): 19-22.

[4] Zhang Xinming, Li Guoxiang. A new teaching model based on modern educational technology [J]. Journal of Anhwei Normal University: Humanities and Social Sciences Edition, 1999 (1): 83-86. 
[5]Peng Shaodong.Research on the design of cooperative learning organization strategy: An Empirical Study Based on the theory of educational technology [D]. Beijing, 2014 